\title{
Fetal Outcome in Pregnancies Complicated with Polyhydraminos: Study Done in Pokhara, Nepal
}

\author{
Gurung SD ${ }^{1 *}$, Shrestha $\mathrm{J}^{1}$, Shrestha $\mathrm{A}^{1}$, Subedi $\mathrm{A}^{1}$, Gyawali $\mathbf{M}^{2}$, Nagila $\mathrm{A}^{3}$ \\ 'Department of Obstetrics \& Gynecology, 'Department of Radiology \& Imaging, \\ Manipal College of Medical Sciences \& Teaching Hospital, Pokhara, Nepal \\ ${ }^{3}$ Department of Biochemistry, Gandaki Medical College \& Teaching Hospital, Pokhara, Nepal
}

Keywords

Cesarean section, Fetal outcome,

Polyhydraminos.

\section{Corresponding author}

*Sangeeta Devi Gurung, MD.

Department of Obstetrics \& Gynecology

Manipal College of Medical sciences \&

Teaching Hospital

E mail: gurungsangita2018@gmail.com

\begin{abstract}
Introduction: Amniotic fluid plays an important role in the development of fetus. Any abnormality in the production amniotic fluid may have adverse effect on the fetus and the mother. Polyhydraminos is one of the common complications occurring during pregnancy and complicates around $0.2-2 \%$ of pregnancies.
\end{abstract}

Methods: It is a prospective study conducted in Manipal Teaching Hospital, Pokhara, Nepal from January 2013 to December 2015. All the pregnant ladies irrespective of gestational age with amniotic fluid index (AFI) $25 \mathrm{~cm}$ or more were enrolled for the study. According to the AFI, polyhydraminos was classified as mild $(25-30 \mathrm{~cm})$, moderate $(30.1-35$ $\mathrm{cm})$ and severe $(>35 \mathrm{~cm})$. Fetal outcome, mode of delivery, presence of congenital anomalies, NICU admission and maternal glucose intolerance were recorded.

Results: Out of 8232 deliveries, 24 were diagnosed and admitted with the diagnosis of polyhydraminos. Mild polyhydraminos, $50 \%$ $(n=12)$ occurred after 37 weeks of gestation and 12.5\% (n=3) had severe polyhydraminos. All pregnant ladies $50 \%(n=12)$, beyond 37 weeks gestation had cesarean section, whereas $25 \%(n=6)$ had vaginal deliveries. $33.3 \%(n=8)$ had preterm labor, $12.5 \%(n=3)$ had premature rupture of membrane, $25 \%(n=6)$ had congenital anomalies, one IUFD, one case of $\mathrm{Rh}$ isoimmunisation and one case of twin pregnancy. NICU admission needed in $20.5 \%(n=5)$. Pregnant ladies with impaired glucose intolerance were $8.3 \%(\mathrm{n}=2)$.

Conclusions: Polyhydraminos is associated with increased incidence of cesarean section, preterm labor, fetal malformation and NICU admission.

\section{INTRODUCTION}

Amniotic fluid (AF) plays an important role for the growth and development of fetus. It also helps in providing nutrients to the fetus, has excretory functions, helps in development of fetal lungs, prevents ascending infections and acts as a shock absorber ${ }^{1}$. Amniotic fluid volume (AFV) is determined by various sources like fetal urination, fetal swallowing reflex, secretions from fetal oral and nasal cavities, fetal lung fluid secretion, movement of water and metabolites between the placenta and the fetal blood and transudation of water and electrolytes across the amnion and chorion. Any disturbance in this mechanism can lead to abnormal production of amniotic fluid ${ }^{2}$. Polyhydraminos, one of the common condition in pregnancy is the excessive accumulation of AF. It complicates $0.2-2 \%$ of pregnancies ${ }^{3,4,5,6}$. It is associated with fetal, placental and maternal causes which may result in adverse fetal and maternal outcome. 
The objective of this study was to assess the fetal outcome in pregnancies complicated with polyhydraminos.

\section{MATERIALS AND METHODS}

This is a prospective study which was carried out in the Department of Obstetrics \& Gynecology, Manipal College of Medical sciences \& Teaching Hospital, Pokhara, Nepal. All pregnant women irrespective of gestational age diagnosed with polyhydraminos and were admitted in the hospital were included in the study. The study period was from January 2013 to December 2015. However, women who were diagnosed with medical problems like heart disease, acute and chronic medical illness were not included in the study. Polyhydraminos was diagnosed by assessing amniotic fluid index (AFI). Various methods have been described to measure the AF. The two most used methods to describe AF are 1) Vertical measurement of the single deepest pocket of amniotic fluid and values more than $8 \mathrm{~cm}$ is considered as polyhydraminos. 2) AFI- dividing the uterus in two halves by an imaginary line and taking the sum of vertical measurement of each of the four quadrants of the amniotic fluid. AFI more than 25 was taken as Polyhydraminos ${ }^{6}$. In this study AFI was taken to assess the polyhydraminos. The degree of polyhydraminos was categorized as mild (AFI 25 $-30 \mathrm{~cm}$ ), moderate (AFI $30.1-35 \mathrm{~cm}$ ) and severe (AFI > 35.1 $\mathrm{cm})^{7}$. During the study period, there were 8232 deliveries and twenty four pregnant ladies without any chronic illness and admitted in the hospital were included in the study. A maternal variable such as age, parity, gestational age and mode of delivery was collected. Neonatal variables like Apgar score, birth weight, gross anomalies detected and NICU admission were collected.

\section{RESULTS}

During the study period from January 2013 to December 2015, there were total 8232 deliveries. Out of them, 24 pregnant ladies were diagnosed as polyhydraminos and admitted in the hospital.

Table 1: Age distribution in relation to AFI

\begin{tabular}{lccc}
\hline Age & \multicolumn{3}{c}{ AFI $(\mathbf{n}=\mathbf{2 4})$} \\
\cline { 2 - 4 } & $\mathbf{2 5 - 3 0}$ & $\mathbf{3 1 . 5}-\mathbf{3 5}$ & $>35$ \\
$<20$ yrs & 1 & - & - \\
$20-30$ yrs & 12 & - & 2 \\
$>30$ yrs & 7 & 1 & 1 \\
\hline
\end{tabular}

In this study, majority of the clients belong to the age group between 20 to 30 years, $58.3 \%(n=14)$ while only one client was under the age group 20 years. Three clients (12.5\%) had AFI more than 35.

Table 2: Parity distribution in relation to AFI

\begin{tabular}{lccc}
\hline Parity & \multicolumn{3}{c}{ AFI $(\mathbf{n}=\mathbf{2 4})$} \\
\cline { 2 - 4 } & $\mathbf{2 5 - 3 0}$ & $\mathbf{3 0 . 1}-\mathbf{3 5}$ & $>\mathbf{3 5}$ \\
P1 & 5 & - & - \\
P2 & 6 & - & 1 \\
P3 & 5 & 1 & - \\
P4 and more & 4 & - & 2 \\
\hline
\end{tabular}

The number of clients in this study was $29.1 \%(n=7)$ belong to Para 2, 25\% (n=6) in both Para 3 and Para 4 and more and only $20.8 \%(n=5)$ were Para 1.

Table 3: AFI in relation to gestational age

\begin{tabular}{lccc}
\hline Gestational age & AFI $\mathbf{2 5}-\mathbf{3 0}$ & $\mathbf{3 1 . 5} \mathbf{- 3 5}$ & $>\mathbf{3 5}$ \\
$<20$ weeks & 1 & - & - \\
$20-28$ weeks & 2 & - & - \\
$29-37$ weeks & 4 & 2 & 3 \\
$>37$ weeks & 12 & - & - \\
\hline
\end{tabular}

This study that the majority of the women were more than 37 weeks of gestation, $50 \%(n=12)$ as compared to those who were between 29 - 37 weeks, 37.5\% ( $n=9), \quad 0.8 \%$ $(n=2)$ were between 20 - 28 weeks and only one ( $0.41 \%)$ was less than 20 weeks of gestation. Majority, $79.2 \%$ $(\mathrm{n}=19)$ had AFI between $25-30 \mathrm{~cm}$ and $12.55(\mathrm{n}=3)$ had AFI $>35 \mathrm{~cm}$

Table 4: Mode of delivery in relation to AFI

\begin{tabular}{lccc}
\hline AFI & $\begin{array}{c}\text { Vaginal } \\
\text { delivery }\end{array}$ & $\begin{array}{c}\text { Elective } \\
\text { cesarean } \\
\text { section }\end{array}$ & $\begin{array}{c}\text { Emergency } \\
\text { cesarean } \\
\text { section }\end{array}$ \\
$25-30$ & 3 & 6 & 10 \\
$31.5-35$ & 2 & - & - \\
$>35$ & 1 & 2 & - \\
\hline
\end{tabular}

This study showed that $75 \% \quad(n=18)$ women with polyhydraminos had cesarean section as compared to only $25 \%(n=6)$ who had vaginal deliveries.

Table 5: Mode of delivery in relation to gestational age

\begin{tabular}{lccc}
\hline $\begin{array}{l}\text { Gestational } \\
\text { Age }\end{array}$ & $\begin{array}{c}\text { Vaginal } \\
\text { delivery }\end{array}$ & $\begin{array}{c}\text { Elective } \\
\text { cesarean } \\
\text { section }\end{array}$ & $\begin{array}{c}\text { Emergency } \\
\text { cesarean } \\
\text { section }\end{array}$ \\
$<20$ weeks & 1 & - & - \\
$20-34$ weeks & 4 & 1 & - \\
$34-37$ weeks & 1 & 2 & 3 \\
$>37$ weeks & - & 4 & 8 \\
\hline
\end{tabular}


This study showed that all the women with gestational age more than 37 weeks of gestation $(n=12)$ had cesarean section as compared to women between 34 - 37 weeks gestation, five out of six had cesarean section. Women with gestational age less than 34 weeks $(n=6)$ had vaginal delivery whereas only one had cesarean section.

Table 6: Outcome of fetus

\begin{tabular}{lcccc}
\hline $\begin{array}{l}\text { Birth } \\
\text { weight }\end{array}$ & $<2 \mathrm{~kg}$ & $2-2.5 \mathrm{~kg}$ & $2.6-3 \mathrm{~kg}$ & $>3 \mathbf{~ k g}$ \\
\cline { 2 - 5 } $\begin{array}{l}\text { NICU } \\
\text { admission }\end{array}$ & $\mathbf{9}$ & $\mathbf{3}$ & $\mathbf{3}$ & $\mathbf{9}$ \\
& 5 & No & IUFD & NND \\
$\begin{array}{l}\text { Congenital } \\
\text { anomalies }\end{array}$ & Yes & No & 1 & 6 \\
& 6 & 18 & & \\
& & & & \\
\hline
\end{tabular}

This study showed that the number of newborns more than three $\mathrm{kg}$ and less than two $\mathrm{kg}$ were equal $(37.5 \%$, $\mathrm{n}=9$ each) and similarly equal number of newborns were between the birth weight $2-2.5 \mathrm{~kg}$ and $2.6-3 \mathrm{~kg}(12.5 \%$, $\mathrm{n}=3$ each). Out of 24 newborns, $20.8 \%(\mathrm{n}=5)$ needed NICU admission, 25\% $(\mathrm{n}=6)$ had congenital anomalies, 25\% $(n=6)$ had neonatal death and one was IUFD.

Table 7: Factors related to polyhydraminos

\begin{tabular}{lccc} 
& AFI- 25-30 & $\mathbf{3 0 . 1}$ - 35 & $>35$ \\
PIH & 2 & - & - \\
PROM & 2 & 1 & - \\
Preterm labor & 5 & 1 & 2 \\
Twin pregnancy & - & - & 1 \\
Rh incompatibility & - & - & 1 \\
Diabetes mellitus & 2 & - & - \\
Congenital anom- & 3 & - & 3 \\
alies & & & - \\
IUFD & - & - & - \\
Cord prolapse & - & - & - \\
PPH & - & & \\
\hline
\end{tabular}

\section{DISCUSSION}

Polyhydraminos is one of the conditions complicating pregnancy and is associated with adverse fetal and maternal outcome. It is also a challenge in obstetric management. Polyhydraminos may result from fetal causes such as decrease swallowing reflex of the fetus as in anencephaly, oesophageal atresia, choanal atresia, tracheoesophageal fistula, intestinal atresia. Other conditions are like increased urinary production, severe anemia, infections (Cytomegalovirus, toxoplasmosis, syphilis, parvovirus) and maternal diabetes ${ }^{2}$.

This study was done to assess the fetal outcome in relation to polyhydraminos, factors associated and the mode of deliveries.

In this study, the majority of the women who were diagnosed with polyhydraminos were in between the age group 21 - 30 years, 58.3\% ( $n=14), 37.5 \% \quad(n=9)$ were more than 30 years and only one was less than 20 years of age. Majority of the patients were parity 2, 29.1\% $(n=7)$, followed by parity 3 and $4(n=6)$ respectively and the least in parity $(20.8 \%, n=5)$. Kaur Tajinder and Sood Ruchika ${ }^{8}$ have also showed in their study that the majority of patients (57.1\%) were in the age group between 27 - 35 years but however the incidence was more in nulliparous women which in contrast to this study which showed the incidence more among multipara, 79.1\% ( $\mathrm{n}=19)$. However in the study conducted by Tashfeen et al $9^{9}$ showed that the incidence of polyhydraminos was more in multiparous $81.1 \%$.

In this study, mild polyhydraminos was more common after 37 weeks of gestation $(50 \%, n=12)$ and severe polyhydraminos was $12.5 \%(\mathrm{n}=3)$ which was found in between 29 - 37 weeks of gestation. Only one pregnant lady had mild polyhydraminos in less than 20 weeks of gestation. The result resembles the study done by Rutwa J. Chavda et $a l^{10}$ which showed that the incidence of polyhydraminos was more $(86 \%)$ in the third trimester. Another study conducted by $\mathrm{C}$ Touboul et al ${ }^{11}$ had observed higher frequency of polyhydraminos at the median gestational age of 39.1 weeks of gestation. Similarly, K Tajunder et $a l^{8}$ had also observed a higher frequency of polyhydraminos (57.1\%) between 29 - 36 weeks of gestation. In this study the incidence of mild polyhydraminos was more, 79.2\% $(\mathrm{n}=19)$ as compared to moderate $8.3 \%(\mathrm{n}=2)$ and severe polyhydraminos $(12.5, \mathrm{n}=3)$. This is similar to the study conducted by Rutwa J Chavda et al ${ }^{11}$ which showed that $55 \%$ had moderately elevated AFI and 6.8\% had markedly elevated AFI. Similarly, the study conducted by Guin G et $a l^{12}$ also showed that $55 \%$ had mild polyhydraminos and only $6.8 \%$ had severe polyhydraminos.

This study showed that $75 \%(\mathrm{n}=18)$ pregnant ladies had cesarean section and only $25 \%(n=6)$ had vaginal deliveries. All the pregnant ladies $(n=12)$ with gestational age more than 37 weeks had cesarean section. However study done by Guin G et $a l^{12}$ and $\mathrm{K}$ Tajunder et $a l^{8}$ had only $22.2 \%$ and $28.6 \%$ cesarean section respectively. This study showed $25 \%(n=6)$ vaginal delivery which contradicts 
the study conducted by Rutwa J Chavda et $a l^{11}$, where the vaginal delivery was $82 \%$. Similarly various studies have also shown higher percentage of vaginal deliveries.

Various studies have shown increased incidence of perinatal morbidity and mortality in pregnancies complicated with polyhydraminos ${ }^{13,14,15}$. Studies conducted by Dashe et al and Damato et al ${ }^{17}$ had $79 \%$ and $63 \%$ of congenital anomalies identified respectively. However, this study showed only $25 \%(n=6)$ pregnant ladies of congenital anomalies. This may be due to the less number of pregnant ladies included in this study. Similarly, studies done by Rutwa J Chavda ${ }^{10}$ also had $31 \%$ of congenital malformation. Kouame $\mathrm{N}$ et $a l^{18}$ and Guin $\mathrm{G}$ et $a l^{12}$ had showed only $1.6 \%$ and $8 \%$ fetal malformation in their studies. This study showed 20.8\% (n=5) NICU admission and one IUFD. Maymon et $a l^{19}$ have observed increased risk of perinatal death and congenital anomalies. Similarly, several studies have shown increased incidence of fetal malformation, increase rate of NICU admission and neonatal death ${ }^{20,21}$.

This study showed that 33.3\% (n=8) had preterm deliveries. Several studies have shown associations of preterm delivery with polyhydraminos. Salih Askin et $a l^{22}$ in their study showed $16.5 \%$ preterm deliveries. Similarly, Pri-Paz et $a l^{23}$ and Dorlejin et $a l^{24}$ reported higher incidence of preterm deliveries up to $20.5 \%$. Ariel $\mathrm{M}$ et al had observed preterm deliveries as high as up to $40 \%$. Similarly, Kaur Tajinnder et $a l^{8}$ has observed higher incidence of preterm deliveries, $40 \%$. In contrast, Kaukab Tashfeen et $a l^{9}$ had observed low incidence of preterm deliveries, $2.5 \%$.

This study showed that $12.5 \%(n=3)$ had premature rupture of membrane. While Rutwa J Chavda et $a l^{10}$ have shown higher incidence of PROM, up to $44.5 \%$. Studies have shown that the risk increases due to over distension of the uterus ${ }^{25}$. Only one pregnant lady in this study had twin pregnancy and one with Rh incompatibility. Rutwa J. Chavda et $\mathrm{l}^{10}$ had also observed $6.6 \%$ of twin pregnancy and $4.4 \% \mathrm{Rh}$ incompatibility in their study. Vasoconstriction leading to uteroplacental insufficiency is associated with oligohydraminos. Pregnancy induced hypertension (PIH) is rarely associated with polyhydraminos. In this study, only $8.3 \%(n=2)$ had PIH which is consisted with the findings done by Kuang Chao et al (3.9\%). However, Rutwa J Chavda ${ }^{10}$ had observed $17.7 \%$ PIH with polyhydraminos.

This study showed that $8.3 \% \quad(n=2)$ had associated impaired glucose tolerance. This is consistent with the study conducted by, Rutwa J Chavda et a ${ }^{10}$ which showed the incidence being 9\%. Studies have shown association between polyhydraminos and maternal pregestational and gestational diabetes ${ }^{26}$. Literature have shown the prevalence of polyhydraminos in gestational diabetes ranging from $8-20 \%{ }^{27}$. Study done by Idris et $a l^{28}$ had shown polyhydraminos among $18.8 \%$ pregnant ladies of gestational diabetes. Similarly, Guin G et al ${ }^{12}$ have also reported $20 \%$ of gestational diabetes associated with polyhydraminos.

\section{CONCLUSION}

In this study, it was observed that polyhydraminos was associated with increased rate of cesarean deliveries. It was also associated with increased risk of preterm labor, congenital anomalies and NICU admission.

\section{REFERENCES}

1. Modena AB, Fieni S. Amniotic Fluid Dynamics. Acta Biomed. 2004; 75: 11-13.

2. Magann EF, Sandlin AT, Qunpraseuth ST. Amniotic fluid and the clinical relevance of the sonographically estimated amniotic fluid volume: Oligohydraminos. J Ultrasound Med. 2011; 30: 1573-1585.

3. Hill LM, Breckle R, Thomas ML, et al. Polyhydraminos: Ultrasonically detected prevalence and neonatal outcome. Obstet Gynecol. 1987; 69: 21-25.

4. Golan A, Wolman I, Langer R, et al. Fetal malformations associated with chronic polyhydraminos in singleton pregnancies. Eur J Obstet Gynecol Reprod Biol. 1992; 47: 185-188.

5. Phelen JP, Martin GI. Polyhydraminos: Fetal and neonatal implications. Clin Perinatal. 1989; 16: 987-994.

6. Mary A, Hill LM, Lazebiuk N, et al. The association between polyhydraminos and preterm delivery. Obstet Gynecol. 1995; 86:389.

7. Hamza A, Herr.D. E.F Solomayer, MeybergSolomayer G. Polyhydraminos: Causes, diagnosis 
and therapy. Geburtshilfe Frauenheilkd. 2013 Dec; 73(12): 1241-1246.

8. Kaur Tr, Sood R. Feto-maternal Outcome in Pregnancies with Abnormal AFI. IOSR-JDMS. 2016; Volume 15, Issue 4: 31-35.

9. Kaukab T, Ilham MH. Polyhydraminos as a predictor of adverse pregnancy outcomes. Sultan Qaboos University Med J. February 2013; Vol 13, issue 1: PP.57-62.

10. Rutwa J.C, Hardev B.S. A prospective clinical study of feto-maternal outcome in pregnancies with abnormal liquor volume. Int J Reprod Contracept Obstet Gynecol. 2014 Mar; 3 (1): 181-184.

11. Toubonl C, Borleau P, Picone O, et al. Outcome of children born out of pregnancies complicated by unexplained polyhydraminos. BJOG an International Journal of Obstetrics and Gynecology. PP 589-492.

12. Guin G, Punekar S, Lele A, et al. A Prospective clinical Study of feto-maternal outcome in pregnancies with abnormal liquor volume. The Journal of Obstetrics \& Gynecology of India. 2011; 61(6): 652-655.

13. Biggo JR Jr, wenstorm $\mathrm{KD}$, Duband $\mathrm{MB}$, et al. Hydraminos prediction of adverse perinatal outcome. Obstet Gynecol. 1999; 94: 773-777.

14. Hashimoto BE, Kaamer DJ, Brennan L. Amniotic fluid volume: Fluid dynamics and measurement technique. Semi ultrasound CT MR. 1993; 14: 40-45.

15. Sarno AP, Ahm M O, Phelan JP. Intrapartum amniotic fluid volume at term. J Reprod Med. 1990; 35: 71923.

16. Dash JS, Mclntire DD, Ramus RM, et al. Hydraminos: Anomaly prevalence and sonographic detection Obstet Gynecol. 2002; 100: 134-9.

17. Damato N, Filly Ra, Goldstein RB, et al. Frequency of fetal anomalies in sonographically detected polyhydraminos. J Ultrasound Med. 1993; 12: 11-15.

18. Kauame N, Goan-Domona AMN, Nikiema Z, et al. Polyhydraminos: A warning sign in the prenatal ultrasound diagnosis of foetal malformation? Diagnostic and International Imaging. 2013; 94: 433-437.

19. Maymon E, Ghezzi F, Shoham-Vardi I. Isolated hydraminos at term gestation and the occurrence of peripartum complications. Eur J Obstet Gynecol Reprod Biol. 1998; 77: 157-161.

20. Magann EF, Doherty DA, Lutgendorf MA, et al. Peripartum outcoomes of high risk pregnancies complicated by oligo- and polyhydraminos: A prospective longitudinal study. J Obstet Gynecol Res. 2010; 32: 268-277.

21. Golan A, Worman J, Sagi J, et al. Persistence of polyhydraminos during pregnancy: Its significance and correlation with maternal and fetal complications. Gynecol Obstet Invest. 1994; 30: 1820.

22. Taskin S, Pabuccu EB, Kanmaz AG, et al. Perinatal outcomes of idiopathic polyhydramnios. Interv Med Appl Sci. 2013 Mar; 5(1): 21-25.

23. Pri-Paz S, Khalek N, Fuchs KM, Simpson LL. Maximal amniotic fluid index as a prognostic factors in pregnancies complicated by polyhydraminos. Ultrasound in Obstetrics and Gynecology, 2012 Jun $1 ; 39(6)$.

24. Dorlejin DM, Cohen-Overbeek TE, Grenendaal F, et al. Idiopathic polyhydraminos and postnatal findings. The Journal of Maternal-fetal and Neonatal Medicine. 2009 Apr 1; 22(4).

25. Adam T. Sandlin, MD, Chauhan SP, et al. Clinical relevance of sonographically estimated amniotic fluid volume. J Ultrasound Med. 2013; 32: 851-863.

26. Kuang-Chao C, Jui-Der L, Tai-Ho, et al. Perinatal Outcomes of polyhydraminos without associated congenital fetal anomalies after the gestational age of 20 weeks. Chang Gung Med J. Vol. 28 No 4.

27. Magann EF, Chauhan SP, Doherty DA, et al. A review of idiopathic hydraminos and pregnancy outcomes. Obstet Gynecol Surv. 2007; 62: 795-802.

28. GardnerG,Mclntyre DH.Influence of polyhydraminos on perinatal outcome in pregestational diabetic pregnancies. Ultrasound Obstet Gynecol. 2010; 36: 338-343. 